\title{
Mechanical ventilation enhances Acinetobacter baumannii-induced lung injury through JNK pathways
}

Tzyy-Bin Tsay ${ }^{1+}$, Wan-Hsuan Chang ${ }^{2 \dagger}$, Ching-Mei Hsu ${ }^{2}$ and Lee-Wei Chen ${ }^{2,3,4^{*}}$ (i)

\begin{abstract}
Background: Patients in intensive care units (ICUs) often received broad-spectrum antibiotic treatment and Acinetobacter baumannii (A.b.) and Pseudomonas aeruginosa (P.a.) were the most common pathogens causing ventilatorassociated pneumonia (VAP). This study aimed to examine the effects and mechanism of mechanical ventilation (MV) on A.b.-induced lung injury and the involvement of alveolar macrophages (AMs).

Methods: C57BL/6 wild-type (WT) and c-Jun N-terminal kinase knockout (JNK1 ${ }^{-/}$) mice received MV for $3 \mathrm{~h}$ at 2 days after nasal instillation of A.b., P.a. $\left(1 \times 10^{6}\right.$ colony-forming unit, CFU), or normal saline.

Results: Intranasal instillation of $10^{6} \mathrm{CFU}$ A.b. in C57BL/6 mice induced a significant increase in total cells and protein levels in the bronchoalveolar lavage fluid (BALF) and neutrophil infiltration in the lungs. MV after A.b. instillation increases neutrophil infiltration, interleukin (IL)-6 and vascular cell adhesion molecule (VCAM) mRNA expression in the lungs and total cells, IL-6 levels, and nitrite levels in the BALF. The killing activity of AMs against A.b. was lower than against P.a. The diminished killing activity was parallel with decreased tumor necrosis factor-a production by AMs compared with A.b. Inducible nitric oxide synthase inhibitor, S-methylisothiourea, decreased the total cell number in BALF on mice receiving A.b. instillation and ventilation. Moreover, MV decreased the A.b. and P.a. killing activity of AMs. MV after A.b. instillation induced less total cells in the BALF and nitrite production in the serum of JNK $1^{-/-}$mice than those of WT mice.

Conclusion: A.b. is potent in inducing neutrophil infiltration in the lungs and total protein in the BALF. MV enhances A.b.-induced lung injury through an increase in the expression of VCAM and IL-6 levels in the BALF and a decrease in the bacteria-killing activity of AMs. A lower inflammation level in $\mathrm{JNK}^{-1-}$ mice indicates that A.b.-induced VAP causes lung injury through JNK signaling pathway in the lungs.
\end{abstract}

Keywords: BALF, VCAM, IL-6, Nitric oxide, Neutrophil, Alveolar macrophages

*Correspondence: chenlw2001@yahoo.com.tw

${ }^{\dagger}$ Tzyy-Bin Tsay and Wan-Hsuan Chang contributed equally to this manuscript

2 Department of Biological Sciences, National Sun Yat-Sen University, Kaohsiung, Taiwan

Full list of author information is available at the end of the article

\section{Background}

Acinetobacter baumannii (A.b.), a non-fermentative, Gram-negative bacillus, is an opportunistic pathogen that can be easily spread [1]. Patients hospitalized in intensive care units (ICUs) often received broad spectrum antibiotic treatment which may lead to frequent isolation of $A . b$. strain from patients [2, 3]. In 2017, A.b. was included in the World Health Organization priority list of antibiotic-resistant bacteria to support research and development of effective drugs [4]. Qiu et al. found that original author(s) and the source, provide a link to the Creative Commons licence, and indicate if changes were made. The images or other third party material in this article are included in the article's Creative Commons licence, unless indicated otherwise in a credit line to the material. If material is not included in the article's Creative Commons licence and your intended use is not permitted by statutory regulation or exceeds the permitted use, you will need to obtain permission directly from the copyright holder. To view a copy of this licence, visit http://creativecommons.org/licenses/by/4.0/. The Creative Commons Public Domain Dedication waiver (http://creativeco mmons.org/publicdomain/zero/1.0/) applies to the data made available in this article, unless otherwise stated in a credit line to the data. 
nicotinamide adenine dinucleotide phosphate hydrogen (NADPH) oxidase appeared to play a crucial role in neutrophil-mediated host defense against $A . b$. and to prevent development of severe disease [5]. Early recruitment of neutrophils into the lungs is critical for initiating an efficient host defense against $A . b$. infection [6]. Macrophages may be involved in early host defense against $A . b$. infection through a more efficient phagocytosis and killing of $A . b$., thus limiting initial pathogen replication and secretion of pro-inflammatory cytokines/chemokines for the rapid recruitment of other innate immune cells such as neutrophils [7]. The management of VAP caused by drugresistant $A . b$. is still a challenge.

Mechanical ventilation (MV) is a lifesaving intervention for patients with respiratory distress. It can maintain normal oxygen supply and improve survival. Typically, MV is administered to at least $40 \%$ of the patients in ICUs in the United States [8]. However, prolonged ventilation or excessive tidal volume can cause serious lung injury in patients, called ventilator-associated lung injury [9] that intensifies lung injury or inflammation and thus increases patient mortality rate [11]. Experimental models demonstrated increased vascular permeability, higher cell count and protein concentration in the bronchoalveolar lavage fluid (BALF) and increased infiltration of inflammatory cells into lung issues in patients with ventilator-induced lung injury patients. Other investigations have also revealed that cytokine/chemokine production, protein leakage, phagocytic response, pulmonary edema and atelectasis could be indications of lung injury [12, 13]. Ventilator-associated pneumonia (VAP) is the most frequent infection in ICUs. A.b. and Pseudomonas aeruginosa (P.a.), which particularly resist carbapenem antibiotics, were reported to be major agents and may cause important therapeutic challenges [14]. Our previous data suggested that the pathogenetic mechanism of VAP caused by P.a. involves tumor necrosis factor (TNF)- $\alpha$ production through the activation of NF- $\mathrm{KB}$ in alveolar macrophages (AMs) and JNK signaling pathway in lung tissues [15]. van Faassen et al. found that the increased susceptibility to $A . b$. of neutropenic mice was associated with a delay in the mRNA expression and production of early pro-inflammatory cytokines in the lungs. These results imply that neutrophils play a critical role in host resistance to respiratory A.b. infection [16]. However, the effects and mechanism of MV on A.b.-induced lung injury has not been characterized.

Airway epithelial cells are the frontline defenders of the lungs against invading microbes by providing a physical barrier and antimicrobial activity [17]. Airway epithelial cells increase the production of mediators such as cytokines, chemokines and antimicrobial peptides in response to such exposure [18]. In response to pathogens, endothelial cells promote inflammation by expressing different combinations of adhesion molecules for leukocytes such as E-selectin, intercellular adhesion molecule-1 and vascular cell adhesion molecule-1 (VCAM-1) in distinct temporal, spatial and anatomical patterns [19]. In this study, nasal instillation of $A . b$. before MV in mice was used as a model to study the mechanism of $A . b$. VAPinduced lung injury.

The objectives of this study were as follows: [1] to determine the mechanism of $A . b$.-induced lung injury, [2] to examine the effects of MV on A.b.-induced lung injury and the involvement of AMs, and [3] to examine the involvement of JNK signaling pathways in A.b. VAP-induced lung injury. Our results suggest that MV enhances $A . b$.-induced lung injury by decreasing the killing activity of AMs and increasing expression of VCAM in the lungs and inflammatory mediators in the BALF.

\section{Methods \\ Animals}

Male C57BL/6 (wild-type, WT) mice weighing from 18 to $25 \mathrm{~g}$ were purchased from National Laboratory Breeding and Research Center (NLBRC, Taipei, Taiwan). JNK1 ${ }^{-/-}$ (c-Jun N-terminal kinases knockout) mice generated from the same background were transferred from Dr. Karin's laboratory (University of California, San Diego, CA, USA). All animals were housed in a temperature controlled room for at least one week before the experiments. All animal procedures were in compliance with regulations on animals used for experimental and other scientific purposes approved by the National Sun Yat-Sen University Animal Experiments Committee.

\section{Experimental design}

In experiment 1 , the animal model of VAP-induced by $A . b$. or P.a. was established. WT mice were anesthetized, instilled with live A.b. or P.a. intranasally, and received MV for $3 \mathrm{~h}$ at 2 days after bacterial instillation. Lung tissues were harvested and assayed for the expression of pro-inflammatory cytokines/chemokines, and BALFs were collected for cell counting and nitrite, protein and cytokine assay.

In experiment $2, \mathrm{WT}$ mice receiving A.b. instillation were given inducible nitric oxide synthase (iNOS) specific inhibitor, S-methylisothiourea (SMT) [20], injection $(7.5 \mathrm{mg} / \mathrm{kg}$, i. p.) at 1 or $2 \mathrm{~h}$ before ventilation to evaluate the effect of iNOS inhibition on A.b. VAP-induced lung injury. Lung tissues and BALFs were harvested and assayed as described in experiment 1 .

JNK1 is the major mediator of iNOS induction [21]. In experiment $3, \mathrm{JNK} 1^{-1-}$ mice were used to study the role of JNK signaling pathways in A.b.-induced VAP. Lung 
tissues were harvested and assayed as described in experiment 1.

\section{Nasal instillation of mice with A.b. or P.a.}

Mice were anesthetized with avertin $(15 \mathrm{mg} / \mathrm{kg})$ and slowly instilled with $10 \mu \mathrm{l}$ of saline containing $1 \times 10^{6}$ colony-forming units (CFU) of live A.b. (a gift from Dr. Te-Li Chen at Taipei Veterans General Hospital in Taiwan), or P.a. (ATCC 9027), or sterile saline (as control) into the lungs via the nostrils. Two days later, mice were sacrificed or received MV for $3 \mathrm{~h}$, and the lungs and BALF were collected for assay.

\section{Mechanical ventilation treatment}

At 2 days after instillation, the mice were sacrificed or received mechanical ventilation for $3 \mathrm{~h}$. Mice were anesthetized with Avertin (15 mg/kg, Sigma), and the neck was cut at $1 \mathrm{~cm}$ below the mouth. The muscles were separated and the trachea was opened and cannulated with a $0.5 \mathrm{~cm} \mathrm{21G}$ needle connected to a mechanical ventilator (SAR-830/P, CWE Inc., Ardmore, PA, USA) with an analog pressure output signal for $3 \mathrm{~h}$. Mice were administered avertin every 20 min during the period of ventilation. The ventilation was with high stretch (tidal volume, $\mathrm{Vt}=30 \mathrm{ml} / \mathrm{kg}$ ) and without positive end expiratory pressure (PEEP).

\section{Tissue preparation}

Mice were sacrificed and the lungs and heart were harvested. Saline $(5 \mathrm{ml})$ was injected into the right ventricle by syringe to clear the blood in pulmonary vasculature. The lung tissue was blotted dry to remove the blood on the surface and immediately stored at $-80{ }^{\circ} \mathrm{C}$ for later use.

\section{Bronchoalveolar lavage fluid (BALF) collection}

Lungs were lavaged twice with $0.5 \mathrm{ml}$ of sterile saline through a tracheal cannula made by a $21 \mathrm{G}$ needle and the BALF was placed into an eppendorf. The number of cells in BALF was counted by using the hemocytometer. The collected BALF was centrifuged at $350 \times \mathrm{g}$, room temperature for $5 \mathrm{~min}$, and the pellet (cells) was used for ex vivo alveolar macrophage stimulation assay or RT-PCR assay. The supernatant was analyzed by Griess assay to quantify nitrite production immediately or frozen at $-80{ }^{\circ} \mathrm{C}$ for Enzyme-Linked immunosorbent assay (ELISA) for cytokine production and for total protein assay.

\section{Neutrophil infiltration of the lungs}

Lung myeloperoxidase (MPO) activity has been used as a marker of lung neutrophil infiltration [22]. Lung tissues were weighed and homogenized in $50 \mathrm{mM}$ potassium phosphate buffer ( $\mathrm{pH}$ 6.0) with $0.5 \%$ hexadecyltrimethylammonium bromide. Homogenates were centrifuged at
$9500 \times g, 4{ }^{\circ} \mathrm{C}$ for $10 \mathrm{~min}$. An aliquot $(60 \mu \mathrm{l})$ of supernatants was added to $939 \mu \mathrm{l}$ of potassium phosphate buffer with $16.7 \mathrm{mg} / \mathrm{ml}$ of O-dianisidine and $0.5 \%$ hydrogen peroxide. The rate of change in absorbance at $460 \mathrm{~nm}$ was measured over $2 \mathrm{~min}$. One unit of MPO activity is defined as the amount of enzyme that reduces $1 \mu$ mole of peroxide per min and the data were expressed as units per gram of lung tissue (Units/g tissue).

\section{Griess assay for nitrite production}

$\mathrm{NO}$ is a mediator of inflammation. The levels of NO are determined by assaying the nitrite level with Griess reaction as described [23]. Equal volumes of $\mathrm{N}$-[1-naphthyl]ethylenediamine (Sigma-Aldrich) and sulfanilic acid (Sigma-Aldrich) are freshly mixed to form the Griess Reagent. The samples $(100 \mu \mathrm{l} /$ well $)$ and a serial dilution of standards $\left(100 \mathrm{mM} \mathrm{NaNO}_{2}\right)$ were put into the microplate and added the prepared Griess reagent $(40 \mu \mathrm{l} /$ well). The plate was incubated at room temperature for $20 \mathrm{~min}$ in the dark. The absorbance at $550 \mathrm{~nm}$ was measured by using an ELISA reader.

\section{Assay for ex vivo stimulation of alveolar macrophages}

Pellets collected after centrifugation of BALF were suspended with RPMI 1640 (Sigma) in 96-well microtiter plates $(200 \mu \mathrm{l} /$ well $)$ and cultured at $37^{\circ} \mathrm{C}$ for $2 \mathrm{~h}$ for attachment. Nonattached cells were washed away and the attached cells (AMs) were stimulated with or without live $P$. aeruginosa or A. baumannii $\left(10^{6} \mathrm{CFU}\right.$ in $\left.200 \mu \mathrm{l}\right)$ at $37^{\circ} \mathrm{C}$ for $4 \mathrm{~h}$. After stimulation, supernatants were collected, incubated in $65^{\circ} \mathrm{C}$ water bath for $1 \mathrm{~h}$, and centrifuged at 9,500 $\times \mathrm{g}$ for $15 \mathrm{~min}$ to remove bacterial cells. The supernatant samples were used for TNF- $\alpha$ levels by ELISA.

\section{Ex vivo bacterial killing activity of alveolar macrophages}

The attached AMs were given $200 \mu \mathrm{l}$ of bacterial suspension containing live $A$. baumannii or $P$. aeruginosa $\left(10^{6} \mathrm{CFU}\right)$ and incubated at $37^{\circ} \mathrm{C}$ for $30 \mathrm{~min}$. After incubation, $100 \mu \mathrm{l}$ of supernatant was diluted and plated onto LB agar plates. The plates were examined for bacterial growth after overnight aerobic incubation at $37^{\circ} \mathrm{C}$. Data were expressed as the percentage when compared to the groups without AMs.

\section{Polymerase chain reaction (PCR) and quantitative real-time} PCR

Total RNAs were extracted from lung tissues or cells from BALF by using the Miniprep Purification Kit (GeneMark). cDNAs encoding pro-inflammatory cytokines and chemokines were generated by reverse transcription and amplified by PCR. Glyceraldehyde3-phosphate dehydrogenase (GAPDH) gene is used 


\section{(See figure on next page.)}

Fig. 1 Mechanical ventilation enhanced Acinetobacter baumannii (A.b.)-induced MPO activity and IL-6 expression in lung tissues. a Mice receiving instillation of $10^{8} \mathrm{CFU}$ of $A$.b. after ventilation demonstrated a significant increase of the MPO activity in the lungs compared with instillation of $10^{8} \mathrm{CFU}$ of $A . b$. $\mathbf{b}$ Expression of TNF-a, IL-1 $\beta$ and IL-6 mRNA in the lungs of WT mice receiving P.a. or A.b. instillation and ventilation. Levels of mRNA expression were detected by real-time PCR. WT mice were intranasal instilled with $1 \times 10^{6} \mathrm{CFU}$ of live A.b. and received mechanical ventilation for $3 \mathrm{~h}$ at 2 days after bacterial instillation. $\mathbf{c}$ Histological examination of the lungs indicated MV after instillations of $10^{6} A \cdot b$. caused significant neutrophil infiltration (arrowhead) and alveolar swelling (arrow) in the lungs. MPO myeloperoxidase, MV mechanical ventilation, BALF bronchoalveolar lavage fluid, TNF tumor necrosis factor, IL interleukin, CFU colony-forming unit, PCR polymerase chain reaction; WT wild type, AL alveolar lumen, wild type, NS normal saline. ${ }^{*} P<0.05,{ }^{*} P<0.01$

as the control and sets of TNF- $\alpha$, iNOS, IL-1 $\beta$, IL-6, ICAM, VCAM, CXCR-2, MIP-2 and GADPH primers were designed according to which documented in the GenBank (additional file 1).

For PCR reactions, $0.2 \mathrm{ml}$ tubes were added $3 \mu \mathrm{l}$ of 10X Gene Taq buffer (GeneMark Inc., Atlanta, GA, USA), $2 \mu \mathrm{l}$ of $2.5 \mathrm{mM}$ dNTP, $0.5 \mu \mathrm{l}$ of $25 \mathrm{mM}$ sense and antisense primers and water to make a total volume of $30 \mu \mathrm{l}$. Each tube was added $0.05 \mu \mathrm{l}$ of Gene Taq DNA polymerase $(5 \mathrm{U} / \mu \mathrm{l})$. The amplification was performed in a thermocycler (Bio-Rad) with the following profile: $5 \mathrm{~min}$ at $95^{\circ} \mathrm{C}$ before the first cycle, $1 \mathrm{~min}$ at $95^{\circ} \mathrm{C}$ for denaturation, $1 \mathrm{~min}$ at $58{ }^{\circ} \mathrm{C}$ for annealing, and $1 \mathrm{~min}$ $30 \mathrm{~s}$ at $72{ }^{\circ} \mathrm{C}$ for extension, finally $10 \mathrm{~min}$ at $72{ }^{\circ} \mathrm{C}$ after the last cycle. The PCR products were separated on a $1.5 \%$ agarose gel and stained with ethidium bromide. The approximate sizes of PCR products were obtained by comparing with the markers (100 bp Ladder, New England Biolabs, Beverly, MA, USA).

\section{Enzyme-linked immunosorbent assay (ELISA)}

Lung tissues, BALF and supernatants collected after ex vivo stimulation of AMs were assayed for TNF- $\alpha$, IL- $1 \beta$ and IL- 6 production by using the mouse ELISA kit (eBioscience). Lung tissues were homogenized in lysis buffer (30 mM Tris, pH 7.5, $300 \mathrm{mM} \mathrm{NaCl,} 2 \mathrm{mM}$ $\mathrm{MgCl}_{2}, 10 \%$ Triton X-100, $2 \mathrm{mM} \mathrm{CaCl}$, and $20 \mu \mathrm{g} / \mathrm{ml}$ of protease inhibitor) and centrifuged at $1000 \times g, 4{ }^{\circ} \mathrm{C}$ for $15 \mathrm{~min}$. The supernatants were collected and used for assay. The ELISA plates were coated with capture antibodies $(100 \mu \mathrm{l} /$ well $)$ at $4{ }^{\circ} \mathrm{C}$ for overnight, then washed several times and blocked with assay buffer (200 $\mu \mathrm{l} /$ well) at room temperature for $1 \mathrm{~h}$. The samples and standards were added to the plates and incubated at $4{ }^{\circ} \mathrm{C}$ for overnight, then, the plates were washed several times. Detection antibodies $(100 \mu \mathrm{l} /$ well $)$ were added for $1 \mathrm{~h}$ and avidin-HRP $(100 \mu \mathrm{l} /$ well $)$ was added for $30 \mathrm{~min}$ at room temperature. Finally, substrate 3,3,5,5'-tetramethylbenzidine was added and incubated at room temperature for $15 \mathrm{~min}$. The reaction was stopped by adding $2 \mathrm{~N} \mathrm{H}_{2} \mathrm{SO}_{4}(50 \mu \mathrm{l} /$ well $)$ and the absorbance at $450 \mathrm{~nm}$ was measured by using an ELISA reader.

\section{Histological study}

Tissue samples were collected and fixed in $4 \%$ formalin for $24 \mathrm{~h}$. The samples were embedded in paraffin, cut into 3-5 $\mu \mathrm{m}$ sections, and stained with hematoxylin and eosin. Infiltration of inflammatory cells and alveolar wall thickening were observed.

\section{Statistics}

All data are analyzed by one-way analysis of variance or T-test analysis of variance (ANOVA), followed by Turkey's Multiple Comparison Test. All values in the figures and text are expressed as mean \pm standard error of the mean. $\mathrm{P}$ values of less than 0.05 are considered to be statistically significant.

\section{Results}

\section{MV enhances $A . b$.-induced neutrophil infiltration} in the lungs

To investigate the effects of MV on A.b.-induced neutrophil infiltration in the lungs, pulmonary myeloperoxidase (MPO) activity was examined in different groups. MV after A.b. instillation of $10^{6}$ or $10^{8} \mathrm{CFU}$ significantly increased neutrophil infiltration in the lungs by two- $(12.72 \pm 4.03$ vs $7.23 \pm 2.11 \mathrm{unit} / \mathrm{g})$ and three-folds $\left(19.64 \pm 2.46\right.$ vs $7.21 \pm 4.09$ unit/g) compared with $10^{6}$ or $10^{8}$ CFU of $A . b$. instillation (Fig. 1a). These results suggest that MV enhances $A . b$.-induced neutrophil infiltration in the lungs.

\section{MV enhances $A$.b.-induced interleukin (IL)- 6 expression and alveolar wall thickening in the lungs}

To examine the effects of MV on A.b.- or P.a.-induced inflammatory cytokine expression in the lungs, expression of tumor necrosis factor (TNF)- $\alpha$, IL-1 $\beta$, and IL-6 mRNA in the lungs were examined in different groups. Either $A . b$. instillation or $\mathrm{MV}$ did not significantly induce the expression of TNF- $\alpha$, IL- $1 \beta$, and IL- 6 in the lungs compared with saline instillation. MV significantly increased the expression of TNF- $\alpha$ mRNA in the lungs of the A.b.+MV group by two-folds compared with the 

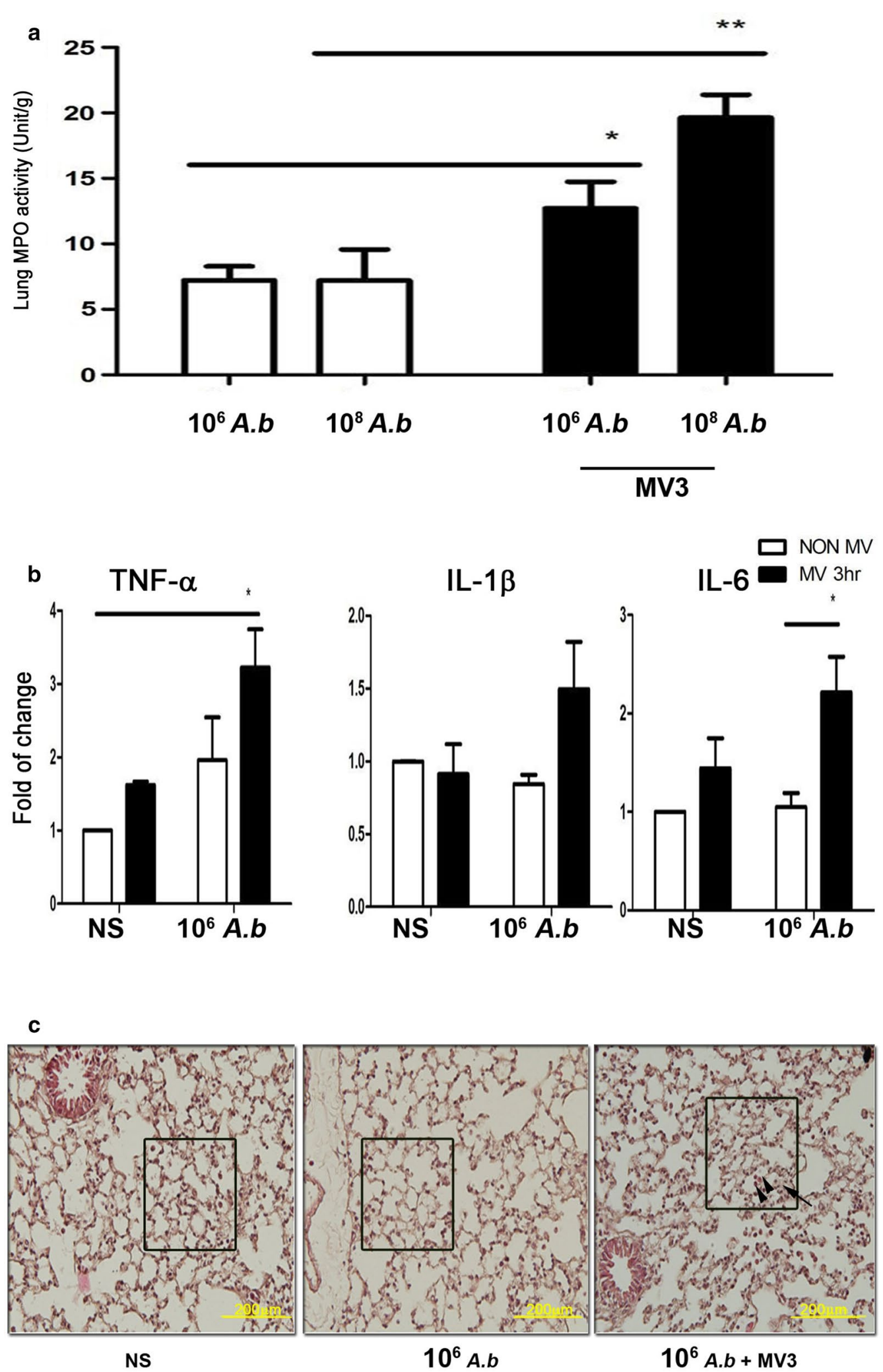


\section{(See figure on next page.)}

Fig. 2 Mechanical ventilation enhanced Acinetobacter baumannii instillation-induced total cells and protein in the BALF. a The effects of mechanical ventilation on $10^{6}$ P. aeruginosa (P.a.) or $10^{6}$ A. baumannii (A.b.) instillation-induced neutrophil infiltration in the lung. WT mice instilled with live P.a., A.b., or normal saline via nostrils 2 days before receiving ventilation for $3 \mathrm{~h}$ and lung tissues were collected and analyzed. MV after instillations of $10^{6}$ A.b. or $10^{6}$ P.a. increased the total cell number $\mathbf{b}$ and protein concentrations $\mathbf{c}$ in the BALF of WT mice. $n=5-6 /$ group. MPO myeloperoxidase, BALF bronchoalveolar lavage fluid, WT wild type, MV mechanical ventilation, NS normal saline. ${ }^{*} P<0.05,{ }^{* *} P<0.01,{ }^{* * *} P<0.001$

saline + MV group (Fig. 1b). IL-6 expression in the lungs of the $A . b .+\mathrm{MV}$ group increased approximately twofolds compared with that in the $10^{6} A . b$. group (Fig. 1b). Histological examination of the lungs indicated ventilation with $10^{6} A . b$. instillation caused infiltration of neutrophils into the lung tissue and alveolar wall thickening compared with A.b. instillation. (Fig. 1c). These results suggest that MV enhances A.b.-induced IL-6 mRNA expression, neutrophil infiltration, and alveolar wall thickening in the lungs.

\section{MV enhances bacteria-induced neutrophil infiltration in the lungs}

To determine the effects of MV on A.b.- or P.a.-induced neutrophil infiltration in the lungs, pulmonary MPO activity was examined in mice receiving $10^{6} A . b$. or $10^{6}$ P.a. instillation. MV significantly enhanced $10^{6}$ A.b.induced neutrophil infiltration in the lungs by twofolds compared with those received $10^{6}$ A.b. instillation $(12.72 \pm 4.03$ vs $7.23 \pm 2.11$ unit/g). MV did not significantly enhance $10^{6}$ P.a.-induced neutrophil infiltration in the lungs compared with those received $10^{6}$ P.a. instillation $(9.54 \pm 2.34$ vs $4.7 \pm 1.06$ unit/g). These results suggest that MV after $A . b$. instillation enhances $A . b$.-induced neutrophil infiltration in the lungs.

\section{MV enhances $A . b$.-induced total cells in the BALF}

To investigate the effects of MV on A.b.- or P.a.-induced total cells in the BALF, the total cells in the BALF were examined in mice receiving $10^{6} A . b$. or $10^{6} P . a$. instillation. Intranasal instillation of $10^{6} A . b$. significantly increased the total cells in the BALF by two-folds compared with normal saline instillation $(11.35 \pm 1.05$ vs $4.95 \pm 0.69 \times 10^{4}$ cells $/ \mathrm{ml}$ BALF) (Fig. $2 \mathrm{~b}$ ). The number of cells in the BALF represents the migration of AMs to defend against the invading microorganisms. MV significantly enhanced $10^{6}$ A.b.-induced total cells in the lungs compared with $10^{6}$ A.b. instillation ( $14.1 \pm 1.23$ vs $11.35 \pm 1.05 \times 10^{4}$ cells $/ \mathrm{ml}$ BALF). Instillation of $10^{6} \mathrm{~A} . b$. before MV also induced a significant increase in the number of total cells in the lungs compared with saline instillation + MV group $\left(14.1 \pm 1.23\right.$ vs $8.1 \pm 1.46 \times 10^{4}$ cells/ $\mathrm{ml}$ BALF). These results indicate that intranasal instillation of $10^{6} A . b$. increases the number of total cells in the BALF and MV after A.b. instillation enhanced them.

\section{MV enhances $A$.b.-induced total protein levels in the BALF} Many experimental studies have used BALF total protein to evaluate lung injury [24]. To explore the effects of MV on A.b.- or P.a.-induced total protein levels in the BALF, total protein levels in the BALF were examined in mice receiving $10^{6}$ A.b. or $10^{6}$ P.a. instillation. The total protein concentrations in the BALF indicate the production of inflammatory cytokines/chemokines in the airway. Intranasal instillation of $10^{6}$ A.b. significantly increased the total protein levels in the BALF by two-folds compared with normal saline instillation $(275.55 \pm 123.79$ vs $98.99 \pm 0.69 \mu \mathrm{g} / \mathrm{ml} \mathrm{BALF}$ ) (Fig. 2c). These results indicate that intranasal instillation of $A . b$. induces total protein levels in the BALF.

\section{MV induces VCAM expression in the lungs}

To examine the effects of MV on A.b.- or P.a.-induced expression of VCAM mRNA in the lungs, pro-inflammatory cytokine/chemokine mRNA in the lungs were examined in different groups. MV, $10^{6}$ A.b., or $10^{6}$ P.a. instillation did not induce VCAM mRNA expression in the lungs. MV after $10^{6}$ A.b. instillation significantly induced VCAM mRNA expression in the lungs compared with A.b. instillation (Fig. 3a). These results indicate that MV enhances $A . b$. instillation-induced VCAM mRNA expression in the lungs, whose lung expression was closely related to MV rather than to A.b. or $10^{6}$ P.a. instillation.

\section{MV induces IL- 6 levels in the BALF}

To study the effects of MV on A.b.- or P.a.-induced cytokine levels in the BALF, the concentrations of IL- 6 in the BALF were examined in different groups. Instillation of $10^{6}$ A.b. or $10^{6}$ P.a. did not induce IL-6 levels in the BALF compared with normal saline instillation (Fig. 3b). However, MV after $10^{6}$ A.b. or $10^{6}$ P.a. instillation significantly increased IL- 6 levels in the BALF compared with $10^{6}$ A.b. or $10^{6}$ P.a. instillation (Fig. 3b). These results indicate that MV after bacterial instillation increases IL-6 levels in the BALF, whose levels were highly related to ventilation rather than to A.b. or $10^{6}$ P.a. instillation.

\section{MV enhances $A . b$.-induced nitrite levels in the BALF}

To determine the effects of MV on $10^{6}$ A.b.- or P.a.induced lung inflammation, BALF was collected for examination of nitrite levels. Instillation of $10^{6} A . b$. or 

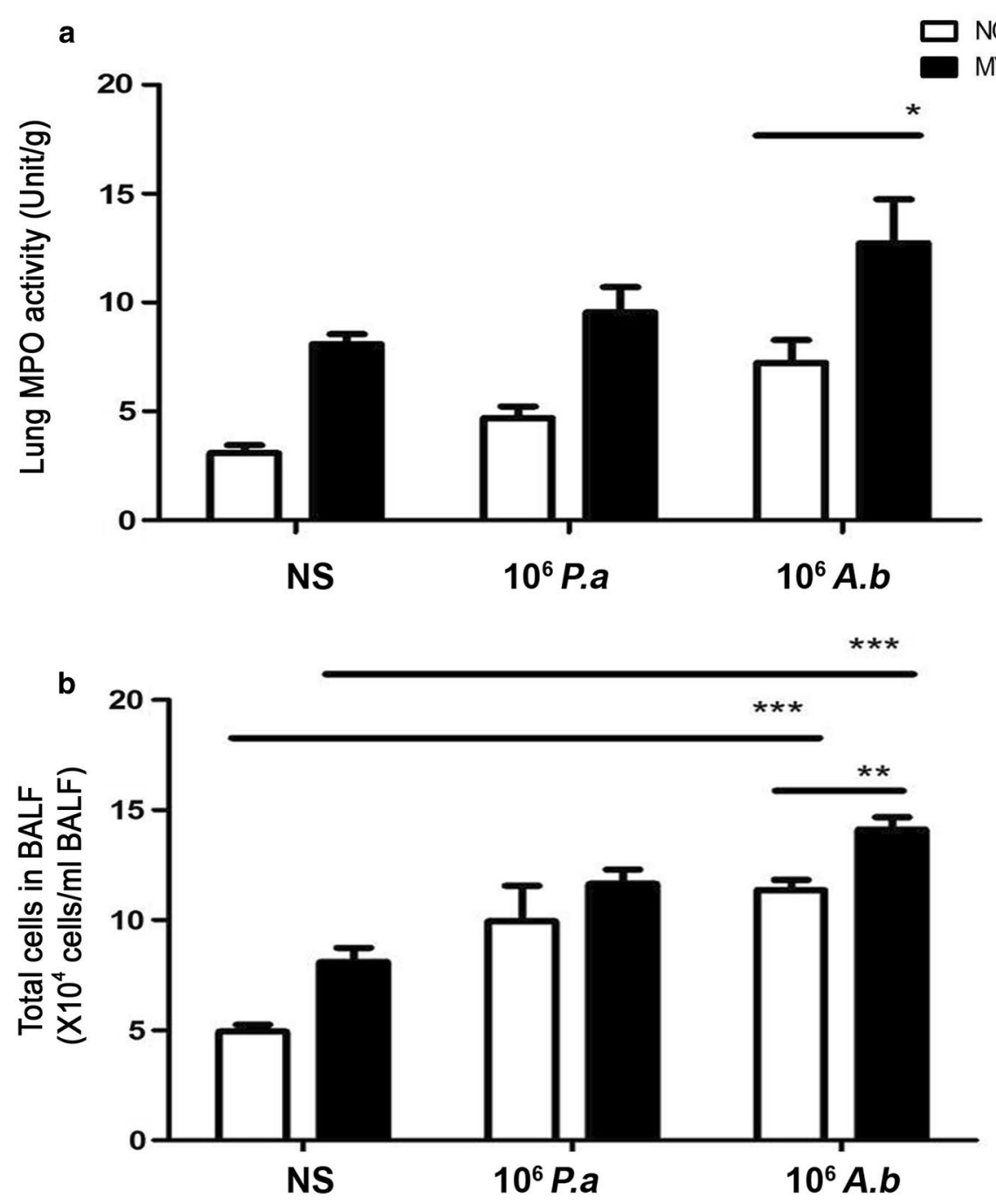

C

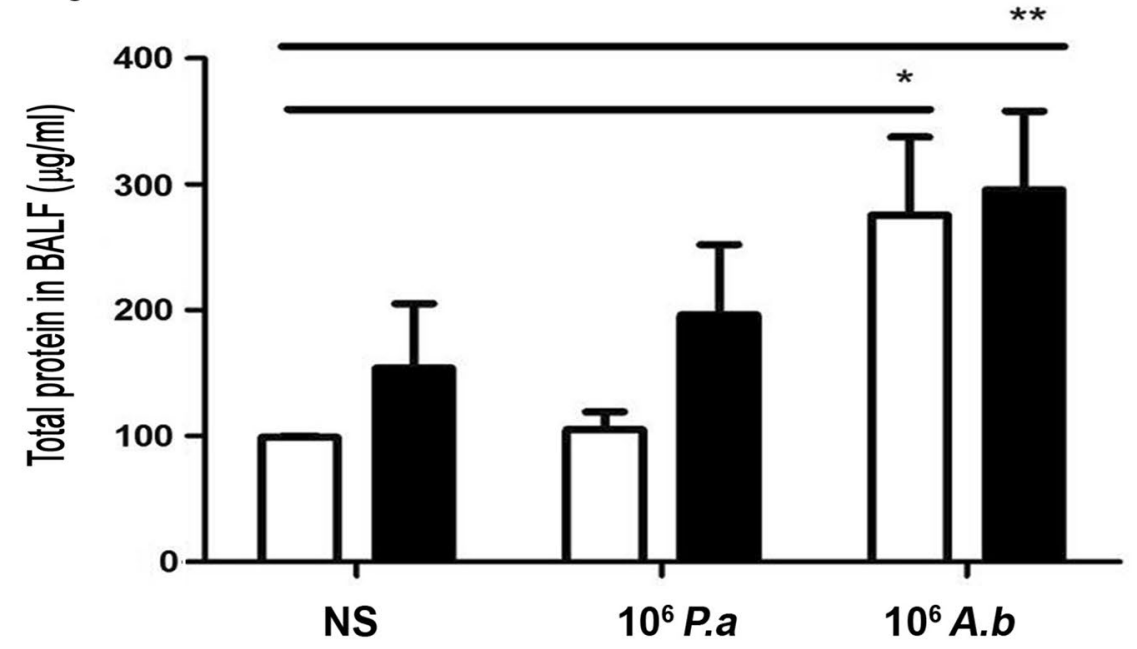




\section{(See figure on next page.)}

Fig. 3 Mechanical ventilation enhanced Acinetobacter baumannii (A.b.) instillation-induced VCAM in the lungs and IL-6 levels and nitrite levels in the BALF. a Expression of VCAM mRNA in the lungs of WT mice receiving P. aeruginosa (P.a.) or A.b. instillation and ventilation. $\mathbf{b} I L-6$ levels in the BALF of WT mice on MV after $10^{6} \mathrm{CFU}$ A.b. or $10^{6} \mathrm{CFU}$ P.a. instillation. Concentrations of IL-6 in the BALF were detected by ELISA. c Nitrite production in the BALF. $10^{6} \mathrm{CFU}$ A.b. instillation induces an increase in the nitrite production in the BALF. WT wild type, MV mechanical ventilation, VCAM vascular cell adhesion molecule, BALF bronchoalveolar lavage fluid, NS normal saline. ${ }^{*} P<0.05,{ }^{* *} P<0.01$

$10^{6}$ P.a. did not induce nitrite levels in the BALF compared with normal saline instillation. However, MV after $10^{6} A . b$. instillation significantly increased nitrite levels in the BALF compared with $10^{6} \mathrm{~A} . b$. instillation $(6.64 \pm 5.55$ vs $2.70 \pm 0.79 \mathrm{nmole} / \mathrm{ml}$ BALF) (Fig. 3c). MV after $10^{6} \quad$ P.a. instillation did not significantly increase nitrite levels in the BALF compared with $10^{6}$ P.a. instillation $(4.5 \pm 1.36$ vs $2.89 \pm 0.98 \mathrm{nmole} / \mathrm{ml}$ BALF). These results suggest that MV after $10^{6} A . b$. instillation significantly increased nitrite levels in the BALF and nitrite is an important mediator in the lung injury caused by MV after $A . b$. instillation.

\section{MV decreases the activity of AMs}

To determine the effects of $10^{6} A . b$. or $10^{6} P$. a. with or without MV on the activity of AMs, AMs were harvested and treated with A.b. or P.a. The production of TNF- $\alpha$ by AMs was significantly increased after ex vivo stimulation with A.b. or P.a. (Fig. 4a). P.a. induced three-folds production of TNF- $\alpha$ by AMs compared with that of $A . b$. After ventilation, TNF- $\alpha$ production by AMs were all decreased with or without stimulation by A.b. or P.a. Moreover, TNF- $\alpha$ production stimulated by $P . a$. was decreased by $16 \%$, and production stimulated by $A . b$. was decreased by $72 \%$ after MV compared with $P . a$. or $A . b$. stimulation. These results indicate that $A . b$. or P.a. treatment stimulates the activity of AMs, P.a. is more potent in stimulating the activity of AMs than A.b., and MV decreases the activity of AMs.

\section{$M V$ reduces the bacteria-killing ability of AMs}

To determine the effects of MV on the bacteria-killing activity of AMs, AMs were harvested with ex vivo incubation of live suspended $10^{6}$ CFU A.b. or P.a. Our data showed that the P.a.-killing ability of AMs isolated after MV was markedly decreased compared with that in the control group (Fig. 4b). Interestingly, the killing ability of AMs against A.b. was constantly and significantly lower than those against P.a. These results suggest that MV decreases the bacteria-killing activity of AMs and that AMs have better killing activity against P.a. than against $A . b$.
Inducible nitric oxide synthase (iNOS) inhibitor decreased the total cell number in BALF

S-methylisothiourea (SMT) is used to investigate the role of iNOS in lung injury induced by $A . b$. instillation after ventilation. SMT injection had no effect on the lung MPO activity after ventilation. SMT treatment significantly decreased the total cell number in BALF (Fig. 5a), indicating the recruitment of cells into airway was decreased. The production of nitrite in BALF was inhibited by SMT injection at $1 \mathrm{~h}$ before ventilation and further decreased $30 \%$ by SMT injection at $2 \mathrm{~h}$ before ventilation (Fig. $5 \mathrm{~b}$ ). Also, the level of nitrite in serum was decreased $50 \%$ by SMT injection at $1 \mathrm{~h}$ before ventilation and $65 \%$ by SMT injection at $2 \mathrm{~h}$ before ventilation respectively (Fig. 5c). Altogether, these results suggest that iNOS inhibitor decreased the total cell number in BALF on mice receiving $A . b$. instillation and ventilation.

\section{MV induces less $A$.b.-induced total cells in the BALF in $\mathrm{JNK}^{-\mathrm{I}}$ mice than in WT mice}

To determine the involvement of JNK1 signaling pathways in the effects of MV A.b.-induced lung injury, total cells in the BALF in JNK1 ${ }^{-/-}$mice were examined. MV after $10^{6} A . b$. instillation induced a significant increase in total cells in the BALF in WT and JNK1 ${ }^{-l-}$ mice compared with $10^{6}$ A.b. instillation (14.2 \pm 1.23 and $10.63 \pm 1.74$ vs $11.35 \pm 1.05$ and $7.17 \pm 2.93 \times 10^{4}$ cells/ ml BALF). MV after $10^{6}$ A.b. instillation induced more total cells in the BALF in WT mice than in JNK1 ${ }^{-1-}$ mice $\left(14.2 \pm 1.23\right.$ vs $10.63 \pm 1.74 \times 10^{4}$ cells/ml BALF) (Fig. 6a). These results suggest that the JNK1 signaling pathway is critical to the stimulatory effect of MV on A.b.-induced total cells in the BALF.

\section{MV enhances $A$.b.-induced VCAM expression in WT mice but not in $\mathrm{JNK} 1^{-/-}$mice}

To determine the involvement of JNK1 signaling pathways in the effects of MV with or without A.b. instillation on lung inflammation, VCAM and MIP-2 mRNA expression of the lung tissues in $\mathrm{JNK} 1^{-/-}$mice was examined. MV significantly enhanced VCAM mRNA expression in the lungs in WT mice but not in JNK1 ${ }^{-1-}$ mice (Fig. 6b). These results suggest that the JNK1 signaling pathway is 

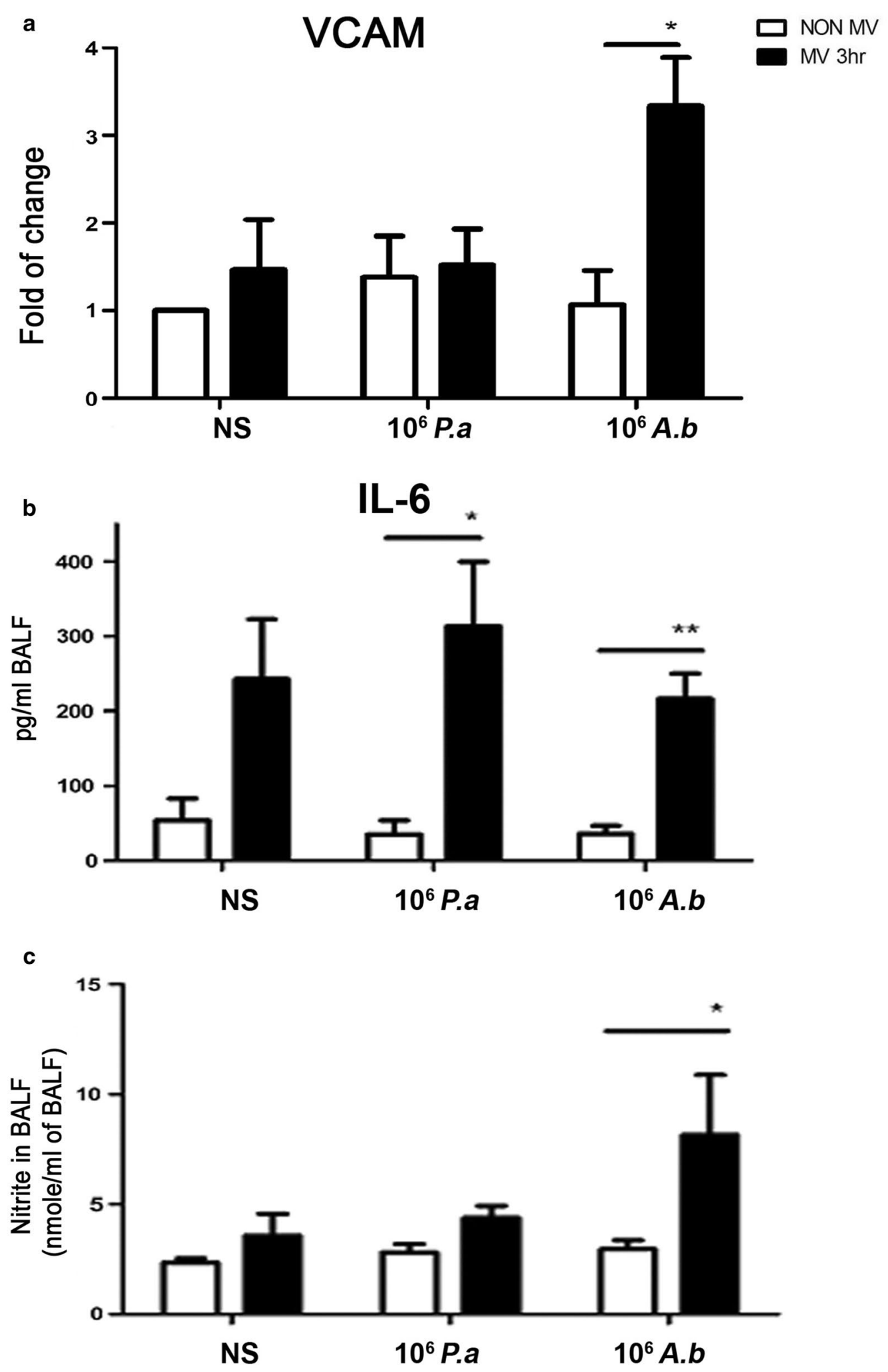

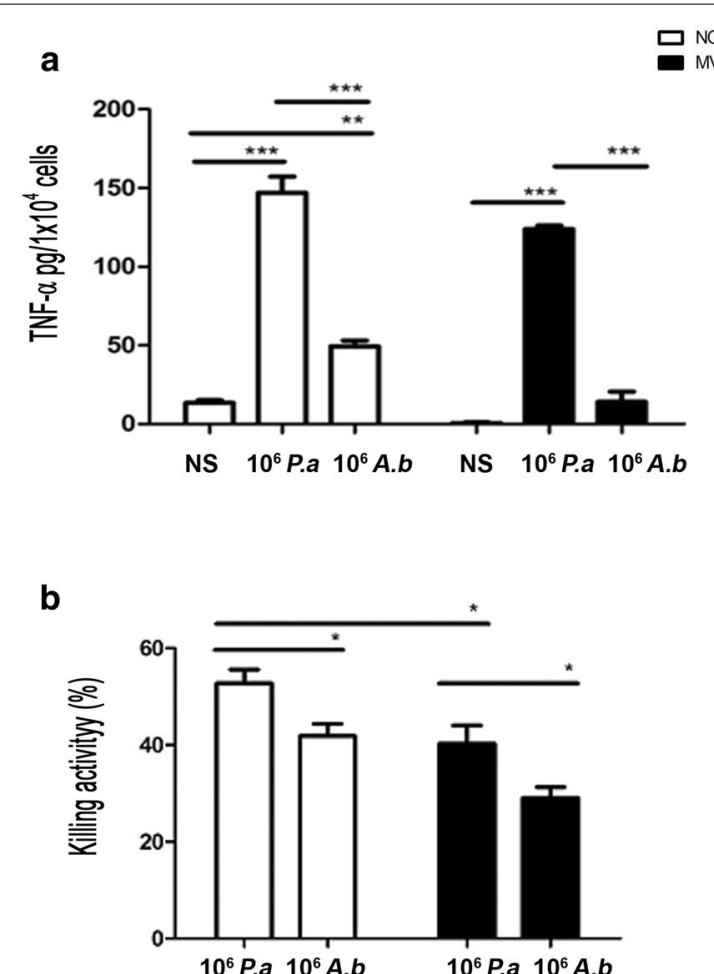

Fig. 4 Mechanical ventilation reduces bacteria-killing activity and activity of alveolar macrophages (AMs). a The production of TNF-a by AMs was significantly increased after ex vivo stimulation with A. baumannii (A.b.) or P. aeruginosa (P.a.). P.a. induced three-folds production of TNF-a by AMs compared with that of A.b. After ventilation, TNF-a production by AMs were all decreased with or without stimulation by A.b. or P.a. AMs isolated from mice were ex vivo stimulated with A.b. or P.a. $\left(10^{6} \mathrm{CFU}\right)$ for $4 \mathrm{~h}$ and the supernatants were examined. The concentrations of TNF-a were determined by enzyme-linked immunosorbent assay. $n=5$ /group. b The bacteria-killing ability of AMs isolated after ventilation was markedly decreased compared with the control group. The killing ability against $A$.b. was constantly and significantly lower than against P.a. before or after ventilation. BALF bronchoalveolar lavage fluid, MV mechanical ventilation, TNF tumor necrosis factor, NS normal saline. ${ }^{*} P<0.05,{ }^{*} P<0.01,{ }^{* * *} P<0.001 . \mathrm{n}=5-6 /$ group

critical to the stimulatory effect of MV-induced VCAM and MIP-2 mRNA expression in the lungs.

\section{MV enhances A.b.-induced nitrite levels in the BALF in WT mice but not in JNK1 ${ }^{-l-}$ mice}

To determine the involvement of JNK1 signaling pathways in the stimulatory effects of MV on inflammation in the BALF, nitrite levels in the BALF in JNK1 ${ }^{-1-}$ mice were examined. MV after $10^{6}$ A.b. instillation significantly enhanced nitrite levels in the BALF compared with $A . b$. instillation in WT mice $(6.64 \pm 5.55$ vs $2.70 \pm 0.79 \mathrm{nmole} / \mathrm{ml}$ BALF) but not in $\mathrm{JNK} 1^{-1-}$ mice

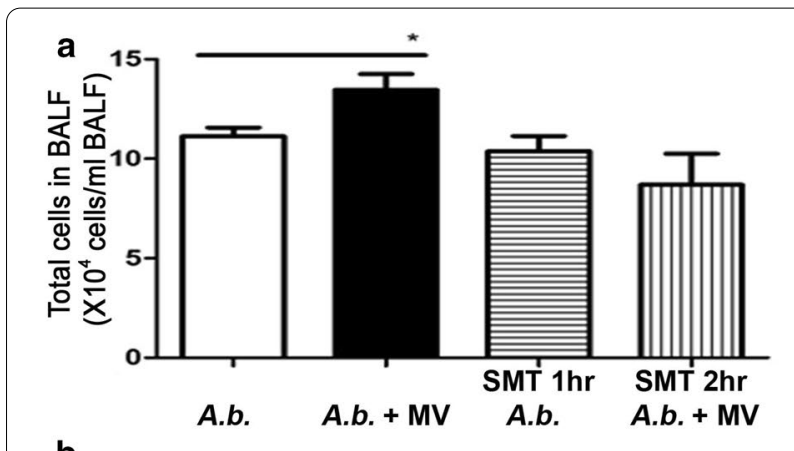

b
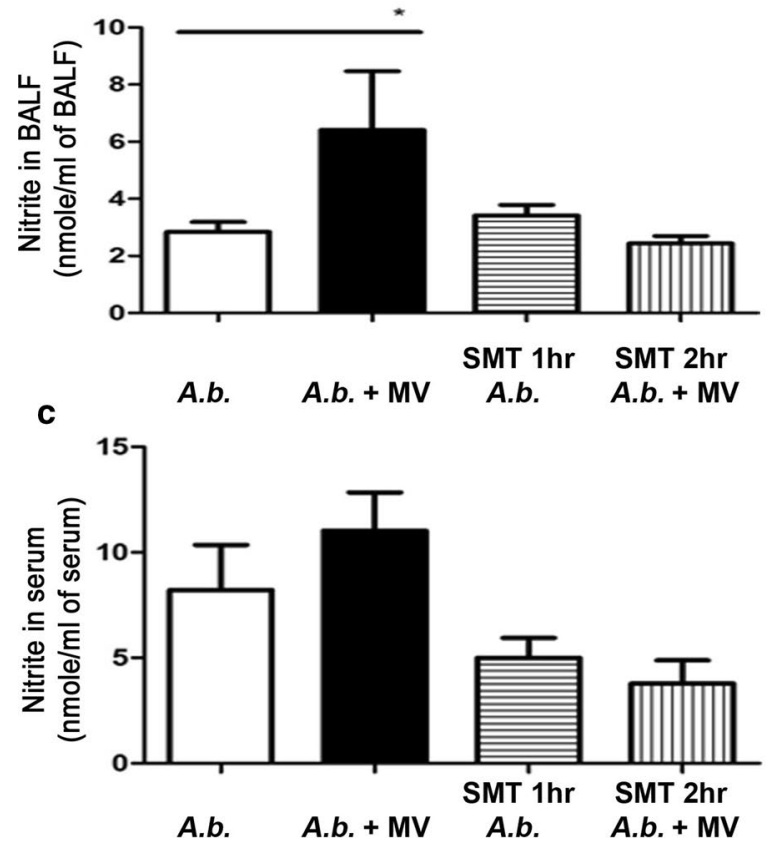

Fig. 5 Acinetobacter baumannii (A.b.) instillation with

S-methylisothiourea (SMT) injection before ventilation decreased the total cell number in BALF of WT mice. a SMT is used to investigate the role of iNOS in lung injury induced by A.b. instillation after ventilation. SMT treatment significantly decreased the total cell number in BALF, indicating that SMT injection before ventilation could prevent the inflammation in BALF. The production of nitrite in BALF $\mathbf{b}$ was inhibited by SMT injection at $1 \mathrm{~h}$ before ventilation and further decreased $30 \%$ by SMT injection at $2 \mathrm{~h}$ before ventilation. Also, the level of nitrite in serum c as decreased $50 \%$ by SMT injection at $1 \mathrm{~h}$ before ventilation and $65 \%$ by SMT injection at $2 \mathrm{~h}$ before ventilation respectively. BALF bronchoalveolar lavage fluid, $M V$ mechanical ventilation, NS normal saline. ${ }^{*} P<0.05 . n=5-6 /$ group

$(3.97 \pm 2.17$ vs $2.70 \pm 1.84 \mathrm{nmole} / \mathrm{ml}$ BALF) (Fig. 6c). MV with $10^{6}$ A.b. instillation induced a significant increase in nitrite levels in the serum of WT mice compared with those of JNK1 $1^{-1-}$ mice $(14.77 \pm 1.90$ vs $4.20 \pm 1.76 \mathrm{nmole} / \mathrm{ml}$ BALF) (Fig. 6d). These results suggest that MV enhances $A . b$.-induced nitrite levels in the BALF and serum through JNK1 signaling pathways 


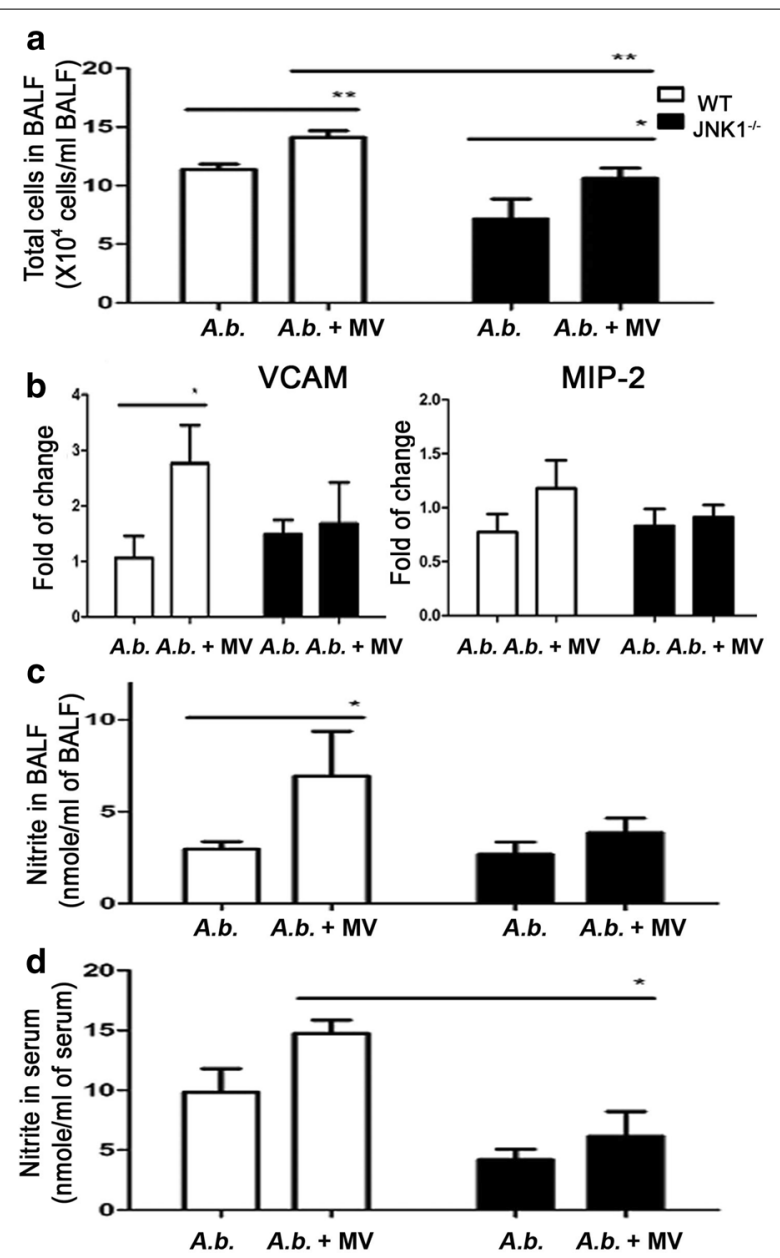

Fig. 6 Mechanical ventilation did not increase Acinetobacter baumannii (A.b.)-induced total cells and nitrite in the BALF, VCAM and MIP-2 expression in the lungs, and nitrite levels in the serum of JNK $1^{-1-}$ mice than those of WT mice. a Total cell counts in the BALF were increased in $\mathrm{JNK}^{-1-}$ mice receiving A.b. and ventilation. $\mathbf{b}$ Expression of pro-inflammatory chemokines and adhesion molecule mRNA in the lungs of WT and $\mathrm{JNK}^{-/-}$mice receiving A.b. instillation and ventilation. VCAM expression was lower in the lungs of $J \mathrm{NK}^{-/-}$ mice than that of WT mice after A.b. instillation and ventilation. $\mathbf{c}, \mathbf{d}$ The nitrite levels in the BALF and serum of WT and JNK1 ${ }^{-/-}$mice receiving A.b. instillation and ventilation. Nitrite production in the BALF and serum was decreased in JNK1 ${ }^{-1-}$ mice. VCAM vascular cell adhesion molecule, BALF bronchoalveolar lavage fluid, NS normal saline. ${ }^{*} P<0.05,{ }^{* *} P<0.01,{ }^{* * *} P<0.001$

and that JNK1 signaling pathways are closely related to MV-induced nitrite levels in the serum.

\section{Discussion}

A.b. is commonly isolated from the hospital environment and hospitalized patients. Multiple factors tend to increase the risk of Acinetobacter infection, including previous antibiotic exposure, ICU admission, and use of catheter, MV, or hemodialysis. Imipenem therapy was the "gold standard" for pneumonia due to A.b. [25]. However, A.b. has rapidly developed resistance to most common types of antibiotics; therefore, the management of VAP caused by drug-resistant $A . b$. is still an ongoing challenge. The possible mechanism of lung injury caused by $A . b$. infection after MV was investigated by using mouse model receiving intranasal instillation of $A . b$. before MV. Our data demonstrated that intranasal instillation of $10^{6} \mathrm{CFU} A . b$. in C57BL/6 mice induced a significant increase in total cells and protein levels in the BALF and neutrophil infiltration in the lungs. MV after $A . b$. instillation increases neutrophil infiltration, expression of IL-6 and VCAM mRNA in the lungs, and total cells, IL- 6 levels, and nitrite levels in the BALF. These results suggest that $A . b$. instillation alone can induce neutrophil infiltration in the lungs through the increase in inflammatory mediators and total cells in the BALF. MV further enhances A.b.-induced neutrophil infiltration through the increase of IL-6 and nitrite levels in the BALF and VCAM mRNA expression in the lungs. These results indicate that protein concentrations in the BALF are easily stimulated by $A . b$. instillation and that MV could stimulate VCAM mRNA expression in the lungs and levels of IL- 6 and nitrite in the BALF through mechanism other than bacterial instillation.

In this study, WT mice with $A . b$. instillation $\left(10^{6} \mathrm{CFU}\right)$ and ventilation showed a considerable increase in lung MPO activity after ventilation but not with P.a. instillation. A significant increase was found in the number of cells in the BALF from mice with $A . b$. instillation but not with P.a. instillation group. After ventilation, the number of cells further significantly increased in mice with A.b. instillation but not with P.a. instillation group. AMs in $\mathrm{C} 56 \mathrm{~B} / 6$ mice showed a greater killing activity for $A . b$. than for P.a.. Altogether, these results suggest that A.b. alone can promote more AMs or neutrophils migration than P.a. . The total protein concentrations in the BALF of WT mice receiving A.b. instillation were significantly increased compared with saline instillation. Interestingly, P.a. instillation alone had no effect on the protein concentrations in the BALF. These results indicate that intranasal $A . b$. instillation can induce a more extensive inflammatory response than P.a. instillation as demonstrated by the protein concentrations in the BALF. These results further suggest that A.b. is better than P.a. in inducing inflammation in the BALF.

The production of several cytokines and chemokines was investigated by different assay methods. Although the increase in TNF- $\alpha$, IL- $1 \beta$ or IL- 6 production was not obvious as assayed by ELISA, the real-time polymerase chain reaction assay showed that $A . b$. instillation alone has no significant effect on the expression of TNF- $\alpha$. The observation of Qiu et al. demonstrated that TNF- $\alpha$ was 
significantly higher in the lungs of C57BL/6 mice soon $(4 \mathrm{~h})$ after infection and depleted quickly after $24 \mathrm{~h} \mathrm{[6].}$ Moreover, the expression of TNF- $\alpha$ in the BALF or lung tissue had no significant difference with or without supplemented ventilation, indicating that the TNF- $\alpha$ is not a key player in VAP caused by A.b. Production of IL-6 is induced by mechanical stress [26]. Our data further demonstrated that the protein levels and mRNA expression of IL-6 was significantly increased in the lungs of mice receiving $A . b$. instillation only after $\mathrm{MV}$, suggesting that IL-6 production is mainly induced by MV but not by bacterial instillation. Previous studies have shown that intranasal administration of MIP-2 induced recruitment of neutrophils into the lungs, which significantly enhanced the resistance of $\mathrm{A} / \mathrm{J}$ mice to intranasal $A . b$. infection and tissue bacterial burden [6]. These results are consistent with our data that VCAM mRNA expression in the lungs of mice receiving $A . b$. instillation was increased after MV.

Qiu et al. [27] summarized the interaction between $A . b$. and found that the host innate immune system was likely to govern the extent of bacterial proliferation and local host inflammatory response following pulmonary bacterial infection. Although macrophages have a relatively minor role in the overall host defense against $A . b$., they play an important role in the initial stage of host defense against A.b.-induced respiratory infection partially through an NO-dependent mechanism. In this study, A.b. instillation after MV induced a significant increase in nitrite levels in the BALF of mice. These observations suggest that induced inducible nitric oxide synthase (iNOS) expression may be involved in the tissue damage caused by $A . b$. after ventilation, a situation similar to the role of $\mathrm{NO}$ production in carbon-tetrachloride-induced acute liver injury [28].

In a previous study, $J N K 1^{-/}$mice receiving P.a. instillation and ventilation showed decreased lung injury compared with WT mice, suggesting that JNK may be an important regulator in the expression of IL-6 in VAP caused by P.a. [29]. Therefore, JNK1 $1^{-l-}$ mice were used to investigate the role of JNK activation in $A . b$. intranasal infection and ventilation in this study. Results of $\mathrm{Li}$ et al. and Limtrakul et al. [30,31] indicated that the possible mechanism of lung damage caused by $A . b$. and ventilation was that $A . b$. instillation would increase the TNF- $\alpha$ production by AMs and activate the NF- $\mathrm{KB}$ pathway, which leads to an increased translation of IL-1 $\beta$. The resultant TNF- $\alpha$ subsequently induces the inflammatory responses through the JNK signaling pathway and finally enhanced the translation of iNOS and IL-6 by activated AP-1. Our data demonstrated that the total cells in the BALF, nitrite levels in the BALF and nitrite levels in the serum were all lower in JNK1 ${ }^{-1-}$ mice receiving A.b. instillation with or without ventilation than in WT mice.
These results indicate a lower inflammation level in the lungs of JNK $1^{-1-}$ mice.

Qiu et al. discovered that many AMs contained high numbers of bacteria within the cytoplasm, but only a few bacteria were visible in the cytoplasm of few neutrophils at $4 \mathrm{~h}$ post infection. The results indicated that $A . b$. induced moderate activation and recruitment of AMs into the lungs and AMs have the ability to clear bacteria immediately after infection [7]. Furthermore, a recent study indicated that TNF- $\alpha$ production was closely related to the killing ability (TNF- $\alpha$-induced killing) [32]. In this study, the result of ex vivo stimulation of AMs isolated from WT mice showed a high level of TNF- $\alpha$ production when stimulated by live P.a., but the TNF- $\alpha$ level was slightly lower when stimulated with live $A . b$. The ex vivo bacteria-killing activity of AMs also showed similar results with TNF- $\alpha$ production when stimulated with $P . a$. or $A . b$. The killing ability of AMs against $A . b$. was lower than against $P . a$., and the ability was decreased regardless if it was against $P . a$. or A.b. after ventilation. Similarly, the ability of AMs to kill $A . b$. was lower than to kill $A . b$. after ventilation. The report of in vitro phagocytosis of $A . b$. by Qiu et al. showed that only $3 \%$ of the bacteria were detected at $4 \mathrm{~h}$ after incubation of $A . b$. with murine macrophage cell line J774A.1 [7]. Compared with the results described above, the bacterial count analysis showed that no colony was detected in the lungs of mice at $48 \mathrm{~h}$ after instillation with either P.a. or A.b., indicating that most of the instilled bacteria were almost cleared in this model. Altogether, our data suggest that the killing activity of AMs against $A . b$. is lower than against P.a. MV treatment decreases AMs' ability to kill A.b. and P.a.

Although macrophages have a relatively minor role in the overall host defense against $A . b$., they play an important role in the initial stage of host defense against respiratory $A . b$. infection partially through an NO-dependent mechanism. In this study, there was a significant increase in the nitrite level in BALF of mice with A.b.instillation after ventilation. Inhibition of iNOS activity by SMT was demonstrated by a decrease in the nitrite level in BALF of mice receiving SMT injection at 1 or $2 \mathrm{~h}$ before ventilation. SMT significantly decreased the total number of cells in BALF. These observations suggest that induced iNOS expression may be involved in the tissue damage caused by $A . b$. after ventilation, a situation similar to the role of NO production in carbon-tetrachloride induced acute liver injury [28].

Our study had several limitations. First, we used a short-term and high stretch mechanical ventilation model (tidal volume, $\mathrm{Vt}=30 \mathrm{ml} / \mathrm{kg}$ ). Future studies using long-term ventilation model may have more clinical relevance. Also, we did not measure lung physiological parameters in our model such as hypoxemia, lung 
compliance, and airway resistance. We estimated lung infiltration of neutrophils based on MPO activity assay. The flow cytometry counting assay using Ly6G may be used to quantify mouse absolute number of neutrophils after instillation of $A . b$. with or without mechanical ventilation in the future.

In conclusion, $A . b$. induced a significant increase in the total cells and protein levels in the BALF and neutrophil infiltration in the lungs. MV after A.b. instillation increases neutrophil infiltration, IL- 6 and VCAM mRNA expression in the lungs and total cells, IL-6 levels, and nitrite levels in the BALF. MV enhances A.b.induced lung injury through the decrease in the killing activity of AMs and increase in VCAM expression and IL-6 levels in the BALF. Lower inflammation level and lung damage in $\mathrm{JNK}^{-1-}$ mice indicates that $A . b$. VAP causes lung injury through JNK signaling pathway in the lungs.

\section{Supplementary Information}

The online version contains supplementary material available at https://doi. org/10.1186/s12931-021-01739-3.

Additional file 1. Supporting information.

\section{Authors' contributions}

WHC conducted the research. $\mathrm{LWC}$ and $\mathrm{CMH}$ designed the research. WHC, TBT and LWC analyzed the data. WHC, CMH, TBT and LWC wrote the article. All authors read and approved the final manuscript.

\section{Funding}

This work was supported by grants from National Science Council (MOST 104-2314-B-010-050), Kaohsiung Veterans General Hospital (VGHKS106-107) to CLW. This work was also supported by grants from Kaohsiung Armed Forces General Hospital Zuoying Branch (ZBH 109-13, ZBH 110-13) to TBT.

\section{Availability of data and materials}

C57BL/6 mice: National Laboratory Breeding and Research Center (NLBRC, Taipei, Taiwan). JNK1 $1^{-1-}$ mice: University of California, San Diego, CA, USA. Avertin: Sigma-Aldrich mechanical ventilator SAR-830/P: CWE Inc., Ardmore, $\mathrm{PA}$, USA protein extraction buffer: Sigma-Aldrich proteinase inhibitor cocktail: Roche Life Science enhanced chemiluminescence detection reagent: Millipore.Biotinylated anti-mouse, anti-rabbit or anti-goat lgG: GenScript USA Inc. Mouse ELISA kit: eBioscience. Primary antibody for western blotting: R\&D Systems.

\section{Declarations}

\section{Ethical approval and consent to participate}

This study was approved by the Institutional Animal Care and Use Committee of Kaohsiung Veterans General Hospital (Permit Number:VGHKS-20162019-A027), and animal experiments were performed according to Animal Experimentation Regulations of Kaohsiung Veterans General Hospital. All efforts were made to minimize suffering.

\section{Consent for publication}

This manuscript does not contain any individual person data.

\section{Competing interests}

The authors declare that they have no competing interests.

\section{Author details}

${ }^{1}$ Department of Surgery, Kaohsiung Armed Forces General Hospital Zuoying Branch, Kaohsiung, Taiwan. ${ }^{2}$ Department of Biological Sciences, National Sun Yat-Sen University, Kaohsiung, Taiwan. ${ }^{3}$ Department of Surgery, Kaohsiung Veterans General Hospital, 386, Ta-Chung 1st Road, Kaohsiung, Taiwan. ${ }^{4}$ Institute of Emergency and Critical Care Medicine, National Yang Ming Chiao Tung University, Taipei, Taiwan.

Received: 15 February 2021 Accepted: 3 May 2021

Published online: 22 May 2021

\section{References}

1. Zander E, Chmielarczyk A, Heczko P, Seifert H, Higgins PG. Conversion of OXA-66 into OXA-82 in clinical Acinetobacter baumannii isolates and association with altered carbapenem susceptibility. J Antimicrob Chemother. 2013;68(2):308-11.

2. Harris G, Kuo Lee R, Lam CK, Kanzaki G, Patel GB, Xu HH, Chen W. A mouse model of Acinetobacter baumannii-associated pneumonia using a clinically isolated hypervirulent strain. Antimicrob Agents Chemother. 2013;57(8):3601-13.

3. Necati Hakyemez I, Kucukbayrak A, Tas T, Burcu Yikilgan A, Akkaya A, Yasayacak A, Akdeniz H. Nosocomial Acinetobacter baumannii infections and changing antibiotic resistance. Pakistan J Med Sci . 2013;29(5):1245-8.

4. Tacconelli E, Carrara E, Savoldi A, Harbarth S, Mendelson M, Monnet DL, Pulcini C, Kahlmeter G, Kluytmans J, Carmeli Y, Ouellette M, Outterson K, Patel J, Cavaleri M, Cox EM, Houchens CR, Grayson ML, Hansen P, Singh N, Theuretzbacher U, Magrini N. Group WHOPPLW: discovery, research, and development of new antibiotics: the WHO priority list of antibioticresistant bacteria and tuberculosis. Lancet Infect Dis. 2018;18(3):318-27.

5. Qiu H, Kuolee R, Harris G, Chen W. Role of NADPH phagocyte oxidase in host defense against acute respiratory Acinetobacter baumannii infection in mice. Infect Immun. 2009;77(3):1015-21.

6. Qiu H, KuoLee R, Harris G, Chen W. High susceptibility to respiratory Acinetobacter baumannii infection in $\mathrm{A} / \mathrm{J}$ mice is associated with a delay in early pulmonary recruitment of neutrophils. Microbes Infect. 2009;1 1 (12):946-55.

7. Qiu H, KuoLee R, Harris G, Van Rooijen N, Patel GB, Chen W. Role of macrophages in early host resistance to respiratory Acinetobacter baumannii infection. PLoS ONE. 2012;7(6):e40019.

8. Esteban A, Anzueto A, Alia I, Gordo F, Apezteguia C, Palizas F, Cide D, Goldwaser R, Soto L, Bugedo G, Rodrigo C, Pimentel J, Raimondi G, Tobin MJ. How is mechanical ventilation employed in the intensive care unit? An international utilization review. Am J Respir Crit Care Med. 2000;161(5):1450-8.

9. Heyland DK, Cook DJ, Griffith L, Keenan SP, Brun-Buisson C. The attributable morbidity and mortality of ventilator-associated pneumonia in the critically ill patient. The Canadian Critical Trials Group. Am J Respir Crit Care Med. 1999;159(4 Pt 1):1249-56.

10. Heyland DK, Cook DJ, Griffith L, Keenan SP, Brun-Buisson C. The attributable morbidity and mortality of ventilator-associated pneumonia in the critically III patient. Am J Respir Crit Care Med. 1999;159(4):1249-56.

11. Budweiser S, Jorres RA, Pfeifer M. Treatment of respiratory failure in COPD. Int J Chron Obstruct Pulmon Dis. 2008;3(4):605-18.

12. Cannizzaro V, Hantos Z, Sly PD, Zosky GR. Linking lung function and inflammatory responses in ventilator-induced lung injury. Am J Physiol Lung Cell Mol Physiol. 2011;300(1):L112-120.

13. Wilson MR, O'Dea KP, Zhang D, Shearman AD, van Rooijen N, Takata M. Role of lung-marginated monocytes in an in vivo mouse model of ventilator-induced lung injury. Am J Respir Crit Care Med. 2009;179(10):914-22.

14. Labarca JA, Salles MJ, Seas C, Guzman-Blanco M. Carbapenem resistance in Pseudomonas aeruginosa and Acinetobacter baumannii in the nosocomial setting in Latin America. Crit Rev Microbiol. 2016;42(2):276-92.

15. Yang YW, Jiang YZ, Hsu CM, Chen LW. Pseudomonas aeruginosa ventilatorassociated pneumonia induces lung injury through TNF-alpha/c-Jun NH2-terminal kinase pathways. PLoS ONE. 2017;12(1):e0169267.

16. van Faassen $H$, KuoLee R, Harris $G$, Zhao X, Conlan JW, Chen W. Neutrophils play an important role in host resistance to respiratory 
infection with Acinetobacter baumannii in mice. Infect Immun. 2007;75(12):5597-608

17. Eisele NA, Anderson DM. Host defense and the airway epithelium: frontline responses that protect against bacterial invasion and pneumonia. J Pathog. 2011. https://doi.org/10.4061/2011/249802.

18. Bals R, Hiemstra PS. Innate immunity in the lung: how epithelial cells fight against respiratory pathogens. Eur Respir J. 2004;23(2):327-33.

19. Bradley JR. TNF-mediated inflammatory disease. J Pathol. 2008:214(2):149-60

20. Szabo C, Southan GJ, Thiemermann C. Beneficial effects and improved survival in rodent models of septic shock with S-methylisothiourea sulfate, a potent and selective inhibitor of inducible nitric oxide synthase. Proc Natl Acad Sci U S A. 1994;91(26):12472-6.

21. Pawate S, Bhat NR. C-Jun N-terminal kinase (JNK) regulation of iNOS expression in glial cells: predominant role of JNK1 isoform. Antioxid Redox Signal. 2006;8(5-6):903-9.

22. Liu YY, Liao SK, Huang CC, Tsai YH, Quinn DA, Li LF. Role for nuclear factor-kappaB in augmented lung injury because of interaction between hyperoxia and high stretch ventilation. Transl Res. 2009;154(5):228-40.

23. Ghazavi A, Mosayebi G, Solhi H, Rafiei M, Moazzeni SM. Serum markers of inflammation and oxidative stress in chronic opium (Taryak) smokers. Immunol Lett. 2013;153(1-2):22-6.

24. Yang YS, Lee YT, Huang TW, Sun JR, Kuo SC, Yang CH, Chen TL, Lin JC, Fung CP, Chang FY. Acinetobacter baumannii nosocomial pneumonia: is the outcome more favorable in non-ventilated than ventilated patients? BMC Infect Dis. 2013;13:142.

25. Garnacho-Montero J, Ortiz-Leyba C, Jimenez-Jimenez FJ, BarreroAlmodovar AE, Garcia-Garmendia JL, Bernabeu-Wittel IM, Gallego-Lara SL, Madrazo-Osuna J. Treatment of multidrug-resistant Acinetobacter baumannii ventilator-associated pneumonia (VAP) with intravenous colistin: a comparison with imipenem-susceptible VAP. Clin Infect Dis. 2003;36(9):1111-8.
26. Ko YA, Yang MC, Huang HT, Hsu CM, Chen LW. NF-kappaB activation in myeloid cells mediates ventilator-induced lung injury. Respir Res. 2013;14:69.

27. KuoLee R, Harris G, Yan H, Xu HH, Conlan WJ, Patel GB, Chen W. Intranasal immunization protects against Acinetobacter baumannii-associated pneumonia in mice. Vaccine. 2015;33(1):260-7.

28. Tipoe GL, Leung TM, Liong E, So H, Leung KM, Lau TY, Tom WM, Fung ML, Fan ST, Nanji AA. Inhibitors of inducible nitric oxide (NO) synthase are more effective than an $\mathrm{NO}$ donor in reducing carbon-tetrachloride induced acute liver injury. Histol Histopathol. 2006;21(11):1157-65.

29. Tsay TB, Jiang YZ, Hsu CM, Chen LW. Pseudomonas aeruginosa colonization enhances ventilator-associated pneumonia-induced lung injury. Respir Res. 2016;17(1):101.

30. Li L, Wang L, Wu Z, Yao L, Wu Y, Huang L, Liu K, Zhou X, Gou D. Anthocyanin-rich fractions from red raspberries attenuate inflammation in both RAW264.7 macrophages and a mouse model of colitis. Sci Rep. 2014;4:6234.

31. Limtrakul P, Yodkeeree S, Pitchakarn P, Punfa W. Anti-inflammatory effects of proanthocyanidin-rich red rice extract via suppression of MAPK, AP-1 and NF-kappaB pathways in Raw 264.7 macrophages. Nutr Res Pract. 2016;10(3):251-8

32. Javelaud D, Wietzerbin J, Delattre O, Besancon F. Induction of p21Waf1/ Cip1 by TNFalpha requires NF-kappaB activity and antagonizes apoptosis in Ewing tumor cells. Oncogene. 2000;19(1):61-8.

\section{Publisher's Note}

Springer Nature remains neutral with regard to jurisdictional claims in published maps and institutional affiliations.
Ready to submit your research? Choose BMC and benefit from:

- fast, convenient online submission

- thorough peer review by experienced researchers in your field

- rapid publication on acceptance

- support for research data, including large and complex data types

- gold Open Access which fosters wider collaboration and increased citations

- maximum visibility for your research: over $100 \mathrm{M}$ website views per year

At BMC, research is always in progress.

Learn more biomedcentral.com/submissions 